\title{
SOCIAL RIGHTS AND THE TURKISH CONSTITUTIONAL COURT
}

\author{
Engin Yıldırım \\ The Constitutional Court of the Republic of Turkey \\ engin.yildirim@anayasa.gov.tr
}

Received: 2 February 2020 | Last Revised: 28 September 2021 | Accepted: 17 November 2021

\begin{abstract}
Through a brief examination of the Turkish experience, this article endeavors to illuminate the debate on the role of constitutional courts in interpreting social rights. The Turkish Constitutional Court has in many cases rejected applications for the annulment of legislation related to social rights, on the grounds that it is within the legislature's discretion to determine public policy priorities based on economic resources and economic stability. This article suggests the Turkish Constitutional Court has narrowly interpreted constitutionally recognized social rights within the boundaries of the Turkish Constitution, with the notable exception of labor rights in individual applications.
\end{abstract}

Keywords: Individual Application, Justiciability, Labor Rights, Social Rights, Turkish Constitutional Court.

\section{INTRODUCTION}

Many countries now embody social rights, along with economic and cultural rights, in their constitutions. Prior to the Second World War, social rights were recognized by only a small number of constitutions. Today, at least one provision on social rights, from within international human rights law, is found in $95 \%$ of 
the constitutions of developing countries, whereas the rate is lower in developed welfare states. ${ }^{1}$ At least 37 state constitutions include non-justiciable 'thick' moral commitments, essentially constitutional directives, which require the state to redistribute income and wealth, and guarantee minimum social rights. ${ }^{2}$ Although some countries, such as Germany, do not recognize social rights in their constitutions, they incorporate the principle of the social state.

Social rights are designed to provide a social safety net by guaranteeing minimum basic needs to lead a life with dignity and self-respect. ${ }^{3}$ It is no coincidence that in the constitutions of 31 countries, social rights are used in association with the concept of human dignity. ${ }^{4}$ Social rights usually include the right to live in dignity, right to social security, right to education, right to health, right to housing, and protection of labor rights. Although these rights are internationally regarded as being as important as civil and political rights, whether they are part of basic rights has long been a controversial issue. ${ }^{5}$ Social rights do not usually have the same status accorded to civil and political rights in terms of enforceability and justiciability, as they are usually interpreted as benefits dispensed by a government willing to allocate scarce resources.

This article gives a brief analysis of social rights adjudication in the Turkish constitutional system. To this end, it investigates whether the Turkish Constitutional Court has demonstrated a judicial willingness and capacity to address various aspects of social rights. Specifically, this article addresses the question of whether a specific pattern or approach can be discerned in social rights case law of the Turkish Constitutional Court.

Lanse Minkler, "Introduction: Why Economic and Social Human Rights," in The State of Economic and Social Human Rights: A Global Overview, ed. Lanse Minkler (New York: Cambridge University Press, 2013 ), 2.

2 Tarunabh Khaitan, "Constitutional Directives: Morally-Committed Political Constitutionalism," The Modern Law Review, 82, no. 4 (2019): 604, https://doi.org/10.1111/1468-2230.12423.

3 Francesca Bignami and Carla Spivack, "Social and Economic Rights as Fundamental Rights," The American Journal of Comparative Law 62 (2014): 563, http://dx.doi.org/10.5131/AJCL.2013.0036.

4 Doron Shulztiner and Guy E. Carmi, "Human dignity in national constitutions: functions, promises and dangers," American Journal of Comparative Law 62, no. 2. (2014): 463, http://dx.doi.org/10.5131/AJCL.2014.0003.

5 James W. Nickel, "Rethinking Indivisibility: Towards a Theory of Supporting Relations between Human Rights," Human Rights Quarterly 30, no. 4 (2008): 985, https://doi.org/10.1353/hrq.0.0046. 


\section{SOCIAL RIGHTS AND THEIR JUSTICIABILITY}

Although social rights constitute an important part of the international human rights corpus and are considered on a par with civil and political rights, their adjudication has not been deeply entrenched in many national and international jurisdictions. This usually emanates from a distinction between justiciable civil and political rights and non-justiciable social rights. It is assumed that while the former does not require any positive governmental action and is relatively cost-free, the latter necessitates such governmental action with intense budgetary implications. ${ }^{6}$ This distinction, however, largely overlooks costs and policy dimensions of civil and political rights. For example, as part of its constitutional obligation to secure due process of law, the state creates judicial bodies financed by the public purse. ${ }^{7}$ In this regard, social rights are similar to constitutionally enshrined fundamental rights in terms of their justiciability. ${ }^{8}$ Despite this, the constitutional status of social rights is often challenged, as they are considered constitutional directives to be implemented by governments within the confines of their policy priorities, rather than being viewed as fundamental rights to be strongly protected by public authorities. ${ }^{9}$

Some scholars strongly object to adjudication of social rights on the grounds of democracy, legitimacy and individual freedom. They argue that while civil and political rights are relatively clear and uncontested, social rights guarantees involve a wide range of highly contested complex and polycentric issues, which should be addressed by popularly elected governments accountable to the people, rather than by the unelected judiciary. ${ }^{10}$ It is has been claimed the judiciary

6 Malcolm Langford, "The Justiciability of Social Rights: From Practice to Theory," in Social Rights Jurisprudence: Emerging Trends in International and Comparative Law, ed. Malcolm Langford (Cambridge: Cambridge University Press, 2009), 14.

Cecile Fabre, "Constitutionalizing social rights," The Journal of Political Philosophy 6, no. 3 (2002): 268.

8 Frank I. Michelman, "The Constitution, Social Rights, and Liberal Political Justification," International Journal of Constitutional Law 1, no. 1 (2003): 16-19, https://doi.org/10.1093/icon/1.1.13.

9 Paul O'Connell, Vindicating Socio-economic Rights: International Standards and Comparative Experiences (Abingdon: Routledge, 2012).

10 Jeanne M. Woods, "Justiciable Social Rights as a Critique of the Liberal Paradigm," Texas International Law Journal 38 (2003): 765; Helena A. Garcia, "Distribution of resources by courts," in Social and Economic Rights in Theory and Practice: Critical Inquiries, eds. Helena A. Garcia, Karl Klare and Lucy A. Williams (Abingdon: Routledge, 2015), 81. 
would disregard the separation of power and democratic governance principles by trespassing on the domains of elected legislative bodies and assuming a function of policy-making in the field of social issues. ${ }^{11}$ Furthermore, it has been stressed that courts cannot deal with large-scale problems as they lack the institutional capacity and the expertise necessary to adjudicate social issues. ${ }^{12}$ There are also concerns that social rights do not deliver their promised outcomes. For example, using annual data from 16o countries between 1960-2010, researchers found that social rights did not, in general, lead to positive effects in education, health and social security. ${ }^{13}$

Although these criticisms are well-founded, the weak enforcement or nonenforcement of social rights may lead to neglect of the interests of people exposed to various economic and social vulnerabilities. ${ }^{14}$ The enforceability of social rights helps create a society where people can lead a life with dignity under more egalitarian economic and social conditions. Governments are, nevertheless, usually inclined to make the realization of social rights conditional on the availability of resources, which means, in practice, deferring their full implementation to a future date. ${ }^{15}$ They also use economic crises as a pretext to cut off public services, leading to further weakening of social rights guarantees. ${ }^{16}$

In addition to indirect constitutional protection, social rights are often adjudicated under the heading of other constitutional rights, such as equality and non-discrimination, property, privacy, right to life, and dignity. In other words, the judiciary can read them into traditional civil rights, such as the right to life.

${ }_{11}$ Lilian Chenwi, "Democratizing the Socio-Economic Rights Enforcement Process," in Social and Economic Rights in Theory and Practice: Critical Inquiries, eds. Helena A. Garcia, Karl Klare and Lucy A. Williams (Abingdon: Routledge, 2015), 182; Kari H. Ragnarsson, "The Counter-Majoritarian Difficulty in a Neoliberal World: Socio-Economic Rights and Deference in Post-2008 Austerity Cases," Global Constitutionalism 8, no. 3 (November 2019): 605, https:// doi.org/10.1017/S2045381719000212.

12 Jeff King, Judging Social Rights (Cambridge: Cambridge University Press, 2012), 33.

13 Christian Bjørnskov and Jacob Mchangama, "Do Social Rights Affect Social Outcomes?" American Journal of Political Science 63, no. 2 (April 2019): 452, https://doi.org/10.1111/ajps.12421.

14 Dennis M. Davis, "Socio-Economic Rights: Has the Promise of Eradicating the Divide Between First and Second Generation Rights Been Fulfilled?" Comparative Constitutional Law, eds. Tom Ginsburg and Rosalind Dixon (Cheltenham: Edward Elgar Publishing, 2011), 524.

15 David Bilchitz, Poverty and Fundamental Rights: The Justification and Enforcement of Socio-Economic Rights (New York: Oxford University Press, 2007), 28.

16 Xenophon Contiades and Alkmene Fotiadou, "Social Rights in the Age of Proportionality: Global Economic Crisis and Constitutional Litigation," International Journal of Constitutional Law 10, no. 3 (2012): 662, https://doi. org/10.1093/icon/moro8o. 
With the exception of some constitutional courts, particularly from the Global South, supreme courts are usually reluctant to change their jurisprudence that prioritizes civil and political rights over social rights. ${ }^{17}$

\section{THE TURKISH EXPERIENCE}

The development of economic and social rights in Turkey can be traced to the 1961 Constitution, which stipulated in Article 2 that the Turkish Republic was a social state, while Article to provided for fundamental rights and social justice.

Although the 1961 Constitution contained a section on social and economic rights, they were not accepted as individual claim rights, as Article 53 of the 1961 Constitution stated: "The state shall carry out its duties to attain the social and economic goals provided in this section only insofar as economic development and its financial resources permit." Hence, the state was obliged to provide those rights as long as financial resources were available to provide them. An individual could not claim that social rights be provided by state organs as there was not any mechanism granting a direct individual application to the court under the provisions of the 1961 Constitution.

Turkey's 1982 Constitution has adopted a similar understanding of social rights in its provisions. Article 2 of the 1982 Constitution, which defines the characteristics of the state and which is an irrevocable provision, stipulates that "Turkey is a democratic, secular and social state governed by the rule of law". Article 5 of the Constitution states that it is a fundamental aim and duty of the state:

"to ensure the welfare, peace, and happiness of the individual and society; to strive for the removal of political, economic, and social obstacles which restrict the fundamental rights and freedoms of the individual in a manner incompatible with the principles of justice and of the social state governed by the rule of law; and to provide the conditions required for the development of the individual's material and spiritual existence."

${ }_{17}$ Natalia Angel-Cabo and Domingo Lovera Parmo, "Latin American Social Constitutionalism: Courts and Popular Participation," in Social and Economic Rights in Theory and Practice: Critical Inquiries, eds. Helena A. Garcia, Karl Klare and Lucy A. Williams (Abingdon: Routledge, 2015), 99. 
Although this article provides the Constitutional Court with a tool to interpret social rights in reviewing of the constitutionality of law, it is rarely used in such reviews.

The 1982 Constitution includes a special section on social and economic rights, encompassing 24 articles. Those rights are generally accepted as policy directives for the Parliament. Furthermore, the Constitution includes a provision setting the limits of social rights. Article 65 of the Constitution stipulates: "The State shall fulfill its duties as laid down in the Constitution in the social and economic fields within the limits of its financial resources, taking into consideration the priorities appropriate with the aims of these duties." On the basis of Article 65, the Turkish Constitutional Court often allows the legislative and the executive to determine economic and social policies as they see fit. Even if the Constitutional Court might desire enforcing constitutionally recognized social rights, Article 65 may be regarded as a bulwark against the justiciability of social rights in the Turkish context. On the other hand, Article 65 also points out that the state has to fulfill its social duties. This is particularly evident if we interpret Article 65 in conjunction with Articles 2 and 5 of the Constitution. Accordingly, social rights cannot be seen merely as non-binding directives for the other branches of power, as Article 65 does not relieve the government from its responsibility to realize the social goals of the Constitution.

When the Turkish Constitutional Court adjudicates social rights cases, it generally adopts a weak form of judicial review, particularly in cases with significant budgetary implications. It has often dismissed annulment claims, indicating the Parliament's discretion to allocate economic resources and budgetary planning. This does not, however, mean the Court has frequently failed to protect social rights. For example, in its review of a statutory provision raising the pension age, the Court held that, in two different rulings, the state is obliged to establish a social security system and provide citizens with social 
benefits. ${ }^{18}$ In a previous ruling, the Court also noted that Article 65 cannot be used as a bulwark for the non-fulfillment of state responsibilities regarding the establishment and maintenance of a social security system. ${ }^{19}$ From the Court's standpoint, the state cannot design and implement policies preventing citizens from enjoying their social rights.

From time to time, the Turkish Constitutional Court has read social rights through the prism of civil and political rights. For example, the right to life, personal inviolability, material and spiritual entity of the individual (Article 17) was used in a number of social security cases regarding the time restriction on payments by health insurers. Different social security schemes specified that medical costs could be covered up to 18 months at the most, regardless of the medical problems. The Court found the relevant provisions of the schemes unconstitutional and annulled them. ${ }^{20}$ For the Court, setting such a time limit infringed the right to life protected by Article 17 of the Constitution, while conditions stipulated in Article 65 could not be valid reasons because the state is compelled to protect the lives of citizens and not to put their lives at risk because of budgetary considerations. ${ }^{21}$ In another case, involving the right to education secured in Article 42 of the Constitution, the Court maintained that the content of a right should not be determined in isolation from the rest of the Constitution. Thus, the Court infused the right to education with the essential guarantees of fundamental rights, elevating it to the status of the first generation rights. ${ }^{22}$

18 Judicial Review of Constitutional Court Law, Decision of Constitutional Court E. 1996/66, K. 1997/7 (The Constitutional Court of the Republic of Turkey, 31 January 1997); Judicial Review of Constitutional Court Law, Decision of Constitutional Court E. 1999/42, K. 2001/41 (The Constitutional Court of the Republic of Turkey, 23 February 2001). The decisions of the Turkish Constitutional Court are available at: https://kararlarbilgibankasi. anayasa.gov.tr.

19 Judicial Review of Constitutional Court Law, Decision of Constitutional Court E. 1993/17, K. $1996 / 38$ (The Constitutional Court of the Republic of Turkey, 1993/17, 18 November 1993).

20 Judicial Review of Constitutional Court Law, Decision of Constitutional Court E. 1996/17, K. 1996/38 (The Constitutional Court of the Republic of Turkey, 16 October 1996).

${ }_{21}$ Judicial Review of Constitutional Court Law, Decision of Constitutional Court E. 2005/52, K. $2007 / 35$ (The Constitutional Court of the Republic of Turkey, 3 April 2007).

22 Judicial Review of Constitutional Court Law, Decision of Constitutional Court E. 1990/4, K. 1990/6 (The Constitutional Court of the Republic of Turkey, 12 April 1990). 
An interesting feature of the Turkish Constitutional Court's social rights jurisprudence is its generally favorable attitude toward civil servants. In its decisions regarding civil servants' social rights, the Court usually emphasizes the constitutional principles of the social state and equality, avoiding using Article 65 in its deliberations. This contradicts its general approach to the adjudication of social rights. The Court appears to have generously protected civil servants from attempts to curtail their social and economic rights. For example, the Court did not hesitate to annul a provision which prevented civil servants from claiming their transportation expenses when being appointed to another city. ${ }^{23}$ While it is reluctant to invoke rights to non-existent social benefits, the Court does not usually allow regressions from existing levels of social services.

In addition to its constitutionality review competency, the Turkish Constitutional Court can hear individual constitutional complaints - a process introduced in 2012 following a constitutional amendment in 2010. The Turkish constitutional complaint system is explicitly restricted to 'classic' rights and freedoms enshrined in both the Constitution and the European Convention for the Protection of Human Rights and Fundamental Freedoms, better known as the European Convention on Human Rights (ECHR). The amended Article 148 of the Constitution stipulates that anyone who claims that his/her constitutional rights set forth in the ECHR have been infringed by a public authority, has the right to apply to the Constitutional Court after exhausting all administrative and judicial remedies. Only the fundamental rights and freedoms set out in the Constitution, which are also guaranteed in the ECHR and its Additional Protocols, may be invoked. This means that individual application has a relatively limited scope of protection against violations of social rights, as it is limited to protect fundamental rights regulated in the ECHR rather than all rights secured in the Turkish Constitution. Violation claims related to social rights are excluded from the individual application mechanism as they do not directly fall under the protection of constitutional complaint but they can be made enforceable

23 Judicial Review of Constitutional Court Law, Decision of Constitutional Court E. 2004/54, K. 2005/24 (The Constitutional Court of the Republic of Turkey, 26 November 2005). 
and amenable to judicial implementation by means of reading and interpreting them into 'classic' rights.

In one of the early violation judgments, the Turkish Constitutional Court protected the right to social security through an interpretation of the right to a fair trial. The applicant, whose arm was amputated as a result of a traffic accident, requested a disability pension from the Social Security Institution (Sosyal Güvenlik Kurumu or SGK). The applicant applied to the SGK on 8 July 2008 and requested a disability pension; but she was referred to hospital by the SGK on 16 February 2010 and subsequently granted a disability pension from 1 April 2010. The applicant requested the pension commence from the date she had lodged the application. She was not paid the pension for a period of 20 months and no response was given with regard to her application. The Court ruled that the applicant's right to a reasoned decision under the scope of the right to a fair trial was violated and ordered the SGK to pay the applicant the disability pension for the period of 20 months between the date she had applied to the SGK and the date she had been granted the pension. ${ }^{24}$

It is, however, in the field of labor rights, rather than other social rights, that the Turkish Constitutional Court has pursued an active approach to safeguard rights of applicants. The main reason for this is that most applications related to labor rights have fallen within the scope freedom of association, which includes the right to unionize. The Court has interpreted this right to include the right to strike and the right to undertake collective agreements. In an individual application by a trade union, the Court found the postponement of a strike in a glass-making company for 6o days on the grounds of public health and national security contravened the trade union rights guaranteed by Article 51 of the Constitution. ${ }^{25}$ The Court maintained that the decision to postpone the strike had rendered the exercise of the constitutional right to strike and collective

24 Individual Application to Constitutional Court, Nurten Esen, Application No. 2013/7970 (The Constitutional Court of the Republic of Turkey, 10 June 2015).

25 Individual Application to Constitutional Court, Kristal-iş̧ Application No. 2014/12166 (The Constitutional Court of the Republic of Turkey, 2 July 2015). 
bargaining practically meaningless. The Court underlined that the decision to postpone the strike was not based on a compelling social need and therefore was not necessary in a democratic society.

In another case, a teachers' union in 2012 instructed its members not to turn up at their workplaces for two consecutive days to protest a new education bill in the Parliament in 2012. Following disciplinary investigations, education authorities cautioned the teachers who took part in the collective action. In response to a number of applications lodged by the cautioned teachers, the Court ruled that the disciplinary sanction imposed on the teachers was a violation that had a chilling effect on their right to unionize and was not necessary in a democratic society. ${ }^{26}$ The same union also called on its members to conduct a similar collective action to protest ISIS attacks in Northern Iraq, resulting in disciplinary fines being imposed on some protesters. In an individual application arising from this case, the Court did not find a violation, pointing out that the union's call for action was not related to core union activities defined as protecting and improving its members' economic, social and cultural interests. ${ }^{27}$ In this decision, the Court developed criteria regarding the circumstances under which the freedom of association may be restricted, making use of the European Court of Human Rights' case law. For the Turkish Constitutional Court, core union activities deal with issues arising from labor relations.

Under neo-liberal economic policies and reformed labor laws, unionization has become increasingly difficult in many parts of the world and Turkey is no exception in this trend. Employers can easily fire their employees who wish to join a union despite the existence of constitutional and statutory laws securing the right to unionize. The Turkish Constitutional Court considers unions as "organized structures aiming to protect the rights and interests of their members" ${ }^{18}$ and has

26 Individual Application to Constitutional Court, Tayfun Cengiz, Application No. 2014/8 18 (The Constitutional Court of the Republic of Turkey, 18 September 2014).

${ }_{27}$ Individual Application to Constitutional Court, Ahmet Parmaksız, Application No. 2017/29263 (The Constitutional Court of the Republic of Turkey, 22 May 2019); Individual Application to Constitutional Court, Dilek Kaya Application No. 2018/14313 (The Constitutional Court of the Republic of Turkey, 4 October 2019).

28 Judicial Review of Constitutional Court Law, Decision of Constitutional Court E. 2013/1, K. 2014/161, \23 (The Constitutional Court of the Republic of Turkey, 22 December 2014). 
determined that unionization is "an important democratic instrument serving the creation of social justice". ${ }^{29}$ Since the Court accepts the right to unionize as a part of the freedom of association, it has also issued violation rulings on this matter. For example, in one case, the applicants, who were not members of a union, had been dismissed on the ground of "underperformance" in their job, whereas they claimed they were fired for attempting to join a labor union..$^{30}$ The Court ruled in favor of the applicants, concluding that joining a union is one of the core tenets of the right to unionize. ${ }^{31}$ Similarly, the Court often holds that individuals are entitled to join and take part in union activities and they should not face any sanctions by employers or public authorities for exercising their constitutional rights. ${ }^{32}$ Moreover, the Court safeguards the right not to join a union and the right to join a union as one's own free choice. ${ }^{33}$ When a local authority exerted pressure on its unionized employees to resign from their union and threatened them with termination of their employment contract, the Court issued a violation ruling upon receiving an individual application from the union. ${ }^{34}$ The Court has also protected unions from interference in their internal management by public authorities or employers. ${ }^{35}$

Although the Turkish Constitutional Court narrowly interprets union activities by confining them to mainly economic issues, there are cases where the Court considers political demands within the scope of lawful union activities. For example, when a union member was fined for displaying a banner that demanded

${ }^{29}$ Judicial Review of Constitutional Court Law, Decision of Constitutional Court E. 2015/62, K. 2015/84, $\ 15$ (The Constitutional Court of the Republic of Turkey, 30 September 2015).

3o Individual Application to Constitutional Court, Anıl Pınar and Ömer Bilge Application No: 2014/15627 (The Constitutional Court of the Republic of Turkey, 5 October 2017).

${ }^{31}$ Individual Application to Constitutional Court Hüseyin Demirdizen, Application No. 2014/11286 (The Constitutional Court of the Republic of Turkey 21 September 2016).

32 Individual Application to Constitutional Court, Eğitim ve Bilim Emekçileri Sendikası ve Diğerleri, Application No. 2014/920 (The Constitutional Court of the Republic of Turkey, 25 May, 2017); Individual Application to Constitutional Court, Abdulvahap Can ve Diğerleri, Application No. 2014/3793 (The Constitutional Court of the Republic of Turkey, 8 November 2017).

33 Individual Application to Constitutional Court Adalet Mehtap Buluryer, Application No. 2013/5447 (The Constitutional Court of the Republic of Turkey, 16 October 2014).

34 Individual Application to Constitutional Court, Türkiye Genel Hizmetler Işçileri Sendikası, Application No. 2016/14475 (The Constitutional Court of the Republic of Turkey, 30 September 2020).

35 Individual Application to Constitutional Court, Tez-Koop-i̇ş Sendikası ve Yalçın Çalışkan, Application No. 2013/6759 (The Constitutional Court of the Republic of Turkey, 3 February 2016). 
education in their mother tongue, the Court concluded that the applicant's right to unionize was violated as a result of the imposition of an administrative fine. ${ }^{36}$

On the other hand, the Court accepts that limitations on trade union rights do not clash with the requirements of a democratic social order as they can be legitimately restricted on national security, public order, public health and general morality grounds, as stipulated in Article 51 of the Constitution. For example, it did not consider bans on strikes in the oil industry, funeral services, and National Defense Ministry workplaces to be unconstitutional. ${ }^{37}$ For the Court, prohibiting strikes in essential services defined as economic activities vital for protecting national security and public health does not constitute disproportionate intervention in the right to strike. ${ }^{38}$ However, in the same decision, the Court unanimously ruled that a ban on strikes in banking and urban public transportation services is unconstitutional. ${ }^{39}$ It argued that "strikes in essential services may result in serious problems for national security and public health but banking and urban public transportation services do not directly affect national security and the whole society". ${ }^{40}$ As a result, the strike bans on these services are incompatible with the requirements of the democratic social order. While the Court does not see a constitutional problem in the prohibition of strikes in essential services, it protects the right to strike in other economic activities and services.

\section{CONCLUDING REMARKS}

The inclusion of social rights in a constitution reflects fundamental social preferences but these do not necessarily translate into public policies. Since justiciability of these rights often results in outcomes with significant economic and political implications, with some notable exceptions in the Global South

\footnotetext{
36 Individual Application to Constitutional Court, Abdulvahap Can ve Diğerleri, Application No. 2014/3793 (The Constitutional Court of the Republic of Turkey, 8 November 2017).

37 Judicial Review of Constitutional Court Law, Decision of Constitutional Court E E. 2013/1, K. 2014/161, 22/10/2014, $\iint 225-226$ (The Constitutional Court of the Republic of Turkey, 22 October 2014).

38 Ibid.

39 Judicial Review of Constitutional Court Law, Decision of Constitutional Court E E. 2013/1, K. 2014/161, 22/10/2014, $\iint 235-236$ (The Constitutional Court of the Republic of Turkey, 22 October 2014).

40 Ibid.
} 
(e.g., South Africa, Columbia and India), courts are generally inclined to remain aloof from this highly controversial area. Not surprisingly, in its social rights case law, the Turkish Constitutional Court shows a reluctance to delve into the detail of how the state allocates resources. The Court has been careful not to cross the separation of powers divide, as it is disinclined to review matters considered to be more the proper domain of the legislative and executive branches. On the other hand, the Court has mainly protected labor rights in cases stemming from individual applications, as it has interpreted these rights as a component of freedom of association. In this way, the Court strives to establish a fair balance between the public interest and the rights and freedoms of individuals. It can be concluded that while the Turkish Constitutional Court is reluctant to implement social rights directly, it does not hesitate to do so when it associates them with civil and political rights.

\section{BIBLIOGRAPHY}

Angel-Cabo, Natalia and Domingo Lovera Parmo. "Latin American Social Constitutionalism: Courts and Popular Participation." In Social and Economic Rights in Theory and Practice: Critical Inquiries, edited by H.A. Garcia, K. Klare and L.A. Williams. Abingdon: Routledge, 2015.

Bignami, Francesca and Carla Spivack. "Social and Economic Rights as

Fundamental Rights." The American Journal of Comparative Law 62, no. 2 (2014). http://dx.doi.org/10.5131/AJCL.2013.0036.

Bilchitz, David. Poverty and Fundamental Rights: The Justification and Enforcement of Socio-Economic Rights. New York: Oxford University Press, 2007.

Bjørnskov, Christian and Jacob Mchangama. "Do Social Rights Affect Social Outcomes?" American Journal of Political Science 63, no. 2 (April 2019), https://doi.org/10.1111/ajps.12421. 
Chenwi, Lilian. "Democratizing the Socio-Economic Rights Enforcement Process." In Social and Economic Rights in Theory and Practice: Critical Inquiries, edited by H.A. Garcia, K. Klare and L.A. Williams. Abingdon: Routledge, 2015.

Contiades, Xenophon and Alkmene Fotiadou. "Social Rights in the Age of Proportionality: Global Economic Crisis and Constitutional Litigation." International Journal of Constitutional Law 10, no. 3 (2012). https://doi. org/10.1093/icon/moro8o.

Davis, Dennis M. "Socio-Economic Rights: Has the Promise of Eradicating the Divide between First and Second Generation Rights been Fulfilled?" In Comparative Constitutional Law, edited by Tom Ginsburg and Rosalind Dixon. Cheltenham: Edward Elgar Publishing, 2011.

Fabre, Cécile. "Constitutionalizing Social Rights." The Journal of Political Philosophy 6, no. 3 (2002).

Garcia, Helena A. "Distribution of Resources by Courts." In Social and Economic Rights in Theory and Practice: Critical Inquiries, edited by H.A. Garcia, K. Klare and L.A. Williams. Abingdon: Routledge, 2015.

Khaitan, Tarunabh. "Constitutional Directives: Morally-Committed Political Constitutionalism." The Modern Law Review 82, no. 4 (2019). https://doi. org/10.1111/1468-2230.12423.

King, Jeff. Judging Social Rights. Cambridge: Cambridge University Press, 2012. Langford, Malcolm. "The Justiciability of Social Rights: From Practice to Theory." In Social Rights Jurisprudence: Emerging Trends in International and Comparative Law, edited by M. Langford. Cambridge: Cambridge University Press, 2009. Michelman, Frank I. "The Constitution, Social Rights, and Liberal Political Justification." International Journal of Constitutional Law 1, no. 1 (2003). https://doi.org/10.1093/icon/1.1.13. 
Minkler, Lanse. "Introduction: Why Economic and Social Human Rights." In The State of Economic and Social Human Rights: A Global Overview, edited by L. Minkler. New York: Cambridge University Press, 2013.

Nickel, James W. "Rethinking Indivisibility: Towards a Theory of Supporting Relations between Human Rights." Human Rights Quarterly 30, no. 4 (2008). https://doi.org/10.1353/hrq.0.0046.

O'Connell, Paul. Vindicating Socio-economic Rights: International Standards and Comparative Experiences. Abingdon: Routledge. 2012.

Ragnarsson, Kári H. “The Counter-Majoritarian Difficulty in a Neoliberal World: Socio-Economic Rights and Deference in Post-2008 Austerity Cases." Global Constitutionalism 8, no. 3 (November 2019). https://doi.org/10.1017/ S2045381719000212.

Shulztiner, Doron and Guy E. Carmi. "Human Dignity in National Constitutions: Functions, Promises and Dangers." The American Journal of Comparative Law 62, no. 2 (2014). http://dx.doi.org/10.5131/AJCL.2014.0003.

Woods, Jeanne M. "Justiciable Social Rights as a Critique of the Liberal Paradigm." Texas International Law Journal 38 (2003). 